\title{
Perbandingan kapasitas vital paru pada pelajar di dataran tinggi Tomohon dengan pelajar di dataran rendah Manado
}

\author{
${ }^{1}$ Rainbow D. Tambunan \\ ${ }^{2}$ Vennetia R. Danes \\ ${ }^{2}$ Fransiska Lintong \\ ${ }^{1}$ Kandidat Skripsi Fakultas Kedokteran Universitas Sam Ratulangi Manado \\ ${ }^{2}$ Bagian Fisika Fakultas Kedokteran Universitas Sam Ratulangi Manado \\ Email: rainbowtambunan12236@gmail.com
}

\begin{abstract}
At an altitude above sea level, the barometric pressure decreases followed by a decrease in air pressure of $\mathrm{O} 2$. If someone stays in a highland for several days, weeks, or years, he/she will become acclimatized. One of the main principles of acclimatization is to increase lung ventilation large enough. This study aimed to determinate the vital lung capacity value of students who lived in highlands and of students who lived in lowlands. This study was conducted in two places: SMA 1 Negeri Tomohon and SMA Negeri 1 Manado in December 2015-February 2016. Samples were 40 students: 20 students of SMA Negeri 1 Tomohon and 20 students of SMA Negeri 1 Manado. This was an analytical study with a cross sectional design. The independent $\mathrm{T}$ test showed that there was no significant difference between Lung Vital Capacity of students in the highland and students in the lowland with a $\mathrm{p}$ value 0.2105. Conclusion: There was no significant difference between Lung Vital Capacity of the students in the highland with students in the lowland.
\end{abstract}

Keywords: students, highlands, lowlands, vital lung capacity

\begin{abstract}
Abstrak: Pada suatu ketinggian di atas permukaan air laut maka tekanan barometrik akan menurun diikuti dengan penurunan tekanan $\mathrm{O}_{2}$ dalam udara. Seseorang yang berada di tempat tinggi selama beberapa hari, minggu, atau tahun akan menjadi semakin teraklimatisasi. Salah satu prinsip utama aklimatisasi ialah peningkatan ventilasi paru yang cukup besar. Penelitian ini bertujuan untuk mengetahui nilai kapasitas vital paru pada pelajar di dataran tinggi dan pelajar di dataran rendah. Penelitian dilakukan di dua tempat yaitu SMA Negeri 1 Tomohon dan SMA Negeri 1 Manado pada bulan Desember 2015-Februari 2016. Sampel penelitian berjumlah 40 siswa yaitu 20 siswa SMA Negeri 1 Tomohon dan 20 siswa SMA Negeri 1 Manado. Jenis penelitian ini analitik dengan desain potong lintang. Hasil uji $\mathrm{T}$ independent menunjukkan tidak ada perbedaan bermakna antara kapasitas vital paru pada pelajar di dataran tinggi dengan pelajar di dataran rendah dengan nilai $\mathrm{p}=0.2105$. Simpulan: Tidak terdapat perbedaan bermakna antara kapasitas vital paru pada pelajar di dataran tinggi dengan pelajar di dataran rendah.
\end{abstract}

Kata kunci: pelajar, dataran tinggi, dataran rendah, kapasitas vital paru

Struktur tubuh manusia di seluruh dunia berbeda satu dengan yang lain. Fakorfaktor seperti genetik, ras, jenis kelamin, aktifitas fisik, nutrisi merupakan beberapa hal yang dapat memengaruhi. Kondisi geografis tempat tinggal manusia juga dapat memengaruhi struktur dari tubuh manusia. Kondisi geografis bumi yang berbeda-beda di setiap wilayahnya akan memberikan rangsangan yang berbeda, sebagai contoh, daerah pantai dan daerah pegunungan akan memberi rangsangan berbeda pada tubuh. Sebagai respons, tubuh akan melakukan adaptasi berpengaruh pada 
keadaan fisiologis.

Indonesia merupakan negara kepulauan yang memiliki lebih dari 17 ribu pulau dengan karakteristik yang berbedabeda, umumnya terdiri dari dataran rendah, dataran tinggi, perbukitan dan pegunungan. ${ }^{1}$ Di Sulawesi, khususnya di Sulawesi Utara, wilayahnya terdiri dari pegunungan dan bukit-bukit, tetapi juga terdapat wilayah dataran rendah. Keadaan geografis Sulawesi Utara ini cocok untuk meneliti kapasitas vital paru seseorang pada dataran tinggi dan dataran rendah.

Kapasitas vital paru adalah volume cadangan inspirasi ditambah volume alun napas dan volume cadangan ekspirasi; ini merupakan jumlah udara maksimum yang dapat dikeluarkan seseorang dari paru, setelah terlebih dahulu mengisi paru secara maksimum dan dikeluarkan sebanyakbanyaknya (kira-kira $4.600 \quad \mathrm{~mL}){ }^{2}$ Kapasitas vital paru ini dapat diukur dengan spirometri yang merupakan tes fungsi paru yang paling sering dilakukan, khususnya volume dan/atau kecepatan aliran udara yang dapat dihirup dan dibuang. ${ }^{3}$

\section{METODE PENELITIAN}

Jenis penelitian ini ialah analitik dengan menggunakan desain potong lintang untuk mengetahui perbandingan kapasitas vital paru pada pelajar di dataran tinggi Tomohon dengan pelajar di dataran rendah Manado. Penelitian ini dilakukan pada bulan Desember 2015 - Februari 2016, dan didapatkan 40 siswa/i yang masuk kriteria inklusi. Penelitian dilakukan di SMA Negeri 1 Tomohon dan SMA Negeri 1 Manado. Pemeriksaan Kapasitas Vital Paru dilakukan di sekolah masingmasing dengan bantuan tenaga dan alat spirometri dari PT. Prodia Widyahusada Manado. Analisis data dilakukan menggunakan program SPSS.

\section{HASIL PENELITIAN}

Penelitian ini dilakukan di 2 tempat dan didapatkan 20 responden di dataran tinggi (SMA Negeri 1 Tomohon) dan 20 responden di dataran rendah (SMA Negeri
1 Manado) dengan total jumlah responden 40 orang. Responden yang memenuhi kriteria inklusi sebanyak 34 orang sedangkan yang tidak memenuhi kriteria sebanyak 6 responden

Pada Tabel 1 didapatkan distribusi responden dimana responden berusia 16 tahun yang terbanyak (44,12\%) dan responden yang berusia 18 tahun yang paling sedikit (2,94\%).

Tabel 1. Distribusi Responden menurut umur

\begin{tabular}{ccc}
\hline Umur & Jumlah & $(\%)$ \\
\hline 15 & 4 & 11,76 \\
16 & 15 & 44,12 \\
17 & 14 & 41,18 \\
18 & 1 & 2,94 \\
Total & 34 & 100,0 \\
\hline
\end{tabular}

Tabel 2 memperlihatkan responden jenis kelamin perempuan (55,88\%) lebih banyak dari yang laki-laki (44,12\%).

Tabel 2. Distribusi Responden menurut jenis kelamin

\begin{tabular}{ccc}
\hline $\begin{array}{c}\text { Jenis } \\
\text { Kelamin }\end{array}$ & Jumlah & (\%) \\
\hline Laki-laki & 15 & 44,12 \\
Perempuan & 19 & 55,88 \\
Total & 34 & 100,0 \\
\hline
\end{tabular}

Berdasarkan Tabel 3, responden dengan tinggi badan $>160 \mathrm{~cm}$ yang terbanyak (50,0\%), diikuti tinggi badan $150-160 \mathrm{~cm}(41,18 \%)$, dan yang paling sedikit responden dengan tinggi badan $<150 \mathrm{~cm}(8,82 \%)$.

Tabel 3. Distribusi tinggi badan responden penelitian

\begin{tabular}{ccc}
\hline $\begin{array}{c}\text { Tinggi } \\
\text { Badan } \\
(\mathrm{cm})\end{array}$ & Jumlah & (\%) \\
\hline$<150$ & 3 & 8,82 \\
$150-160$ & 14 & 41,18 \\
$>160$ & 17 & 50,0 \\
Total & 34 & 100,0 \\
\hline
\end{tabular}

Pada Tabel 4, responden dengan berat 
badan 50-60 $\mathrm{kg}$ dan responden dengan berat badan $>60 \mathrm{~kg}$ masing-masing sebanyak 14 orang (41,18\%) sedangkan yang paling sedikit ialah responden dengan berat badan $<50 \mathrm{~kg}$ sebanyak 6 orang $(17,64 \%)$

Tabel 4. Distribusi berat badan responden penelitian

\begin{tabular}{ccc}
\hline $\begin{array}{c}\text { Berat badan } \\
(\mathrm{kg})\end{array}$ & Jumlah & $\mathbf{( \% )}$ \\
\hline$<50$ & 6 & 17,64 \\
$50-60$ & 14 & 41,18 \\
$>60$ & 14 & 41,18 \\
Total & 34 & 100,0 \\
\hline
\end{tabular}

Tabel 5 merupakan distribusi responden menurut IMT dengan hasil sebagian besar $(73,53 \%)$ memiliki IMT normal.

Tabel 5. Distribusi responden menurut Indeks Massa Tubuh (IMT)

\begin{tabular}{ccc}
\hline $\begin{array}{c}\text { Berat Badan } \\
(\mathrm{kg})\end{array}$ & Jumlah & $\mathbf{( \% )}$ \\
\hline$<18,5$ & 0 & 0 \\
$18,5-25$ & 14 & 73,53 \\
$>25$ & 9 & 26,47 \\
Total & 34 & 100,0 \\
\hline
\end{tabular}

Pada Tabel 6 didapatkan rerata kapasitas vital paru pada dataran tinggi $100,11 \%$ dan yang di dataran rendah 102,70\%. Setelah dilakukan Uji T Independent diperoleh nilai $\mathrm{p}=0,2105$.

Tabel 6. Uji $\mathrm{T}$ Independent Kapasitas Vital Paru responden penelitian

\begin{tabular}{ccc}
\hline & $\begin{array}{c}\text { Rerata } \\
(\%)\end{array}$ & $\mathrm{P}$ \\
\hline Dataran tinggi & $\begin{array}{l}100,11 \\
102,70\end{array}$ & 0,2105 \\
Dataran rendah & \\
\hline
\end{tabular}

\section{BAHASAN}

Rerata nilai kapasitas vital paru pada dataran tinggi sebesar 100,11 \% dan pada dataran rendah sebesar 102,70\%. Nilai kapasitas vital paru dapat dipengaruhi faktor usia, jenis kelamin, status gizi, frekuensi latihan fisik, penyakit paru, dan kebiasaan merokok. ${ }^{3-5}$

Setelah dilakukan uji $\mathrm{T}$ Independent didapatkan nilai kemaknaan $\mathrm{p}=0,2105$ yang menunjukkan tidak terdapat perbedaan bermakna antara rerata kapasitas vital paru pada pelajar di dataran tinggi dengan yang di dataran rendah. Hasil tersebut berbeda dengan hasil penelitian yang dilakukan Kapoor dan Kapoor terhadap penduduk di daerah Ladakh dan Tibet, dengan nilai VC, FVC, dan IC yang lebih besar pada penduduk dataran tinggi. ${ }^{6}$

Hasil uji yang tidak signifikan selain disebabkan oleh faktor seperti usia, jenis kelamin, penyakit paru, merokok, aktivitas fisik, dan lamanya tinggal, faktor perbedaan ketinggian yang tidak terlalu besar juga dapat memengaruhi. Diketahui Tomohon berada di ketinggian 700-800 mdpl dan Manado 0-240 mdpl. ${ }^{7,8}$ Perbedaan ke dua tempat sekitar 560-800 m dengan penurunan tekanan barometrik dari $760 \mathrm{mmHg}$ menjadi $523 \mathrm{mmHg}$, penurunan $\mathrm{PO}_{2}$ dalam udara dari $150 \mathrm{mmHg}$ menjadi $110 \mathrm{mmHg}$, dan penurunan $\mathrm{PO}_{2}$ alveoli dari $104 \mathrm{mmHg}$ menjadi $67 \mathrm{mmHg}$ akan terjadi pada kenaikan $10.000 \mathrm{ft}$ (3.048 m). Di Kota Tomohon dengan ketinggian 700-800 mdpl, hanya terjadi penurunan tekanan barometrik sebesar 54,42-62,2 $\mathrm{mmHg}$, penurunan $\mathrm{PO}_{2}$ dalam udara sebesar 9-10,5 mmHg, dan penurunan $\mathrm{PO}_{2}$ alveolus sebesar 8,5-9,7 mmHg. Penurunan nilai yang terjadi pada tekanan barometrik, $\mathrm{PO}_{2}$ Udara, dan $\mathrm{PO}_{2}$ alveoli ialah $<10 \%$. Nilai persentase yang rendah ini diperkirakan menjadi salah satu faktor yang menyebabkan rerata nilai Kapasitas Vital Paru Responden di kedua tempat tidak jauh berbeda sehingga hasil uji tidak bermakna.

\section{SIMPULAN}

Berdasarkan hasil penelitian dapat disimpulkan bahwa tidak terdapat perbedaan bermakna kapasitas vital paru antara pelajar di dataran tinggi dan pelajar di dataran rendah.

\section{SARAN}

1. Pada penelitian selanjutnya dapat 
digunakan variabel yang lain seperti frekuensi latihan fisik, kebiasaan merokok, dan riwayat penyakit paru.

2. Pada penelitian selanjutnya dianjurkan untuk menambah jumlah responden dan dilakukan di tempat yang memiliki perbedaan dataran tinggi dan rendah yang lebih besar untuk mendapatkan hasil yang lebih baik.

\section{DAFTAR PUSTAKA}

1. Sungkawa D. Letak, Topografi, dan Geologi di Indonesia. [cited 2015 oct 3]. Available from: http://file.upi.edu/Direktori/FPIPS/JUR. _PEND._GEOGRAFI/1955021019800 21-DADANG_SUNGKAWA/ letak_Indonesia.pdf

2. Guyton AC, Hall JE. Ventilasi Paru. In: Buku Ajar Fisiologi Kedokteran. Jakarta: EGC, 2007; p. 500.

3. Baiq EP. Analisis faktor yang mempengaruhi kapasitas vital paru pada ibu hamil di RB Sri Lumintu Jajar Laweyan Surakarta. 2012. [cited 2015 Oct 15]. Available from: http://eprints.ums.ac.id/21946/15/02._N askah_Publikasi.pdf

4. Prasetyo DR. Faktor-faktor yang berhubungan dengan kapasitas vital paru pada pekerja bengkel las di Pisangan Ciputat tahun 2010. 2010. [cited 2015 Oct 15]. Available from: http://repository.uinjkt.ac.id/dspace/bits tream/123456789/1021/1/DIAN\%20R AWAR\%20PRASETYO-FKIK.pdf

5. Nugraha RF. Tingkat kapasitas vital paru siswa yang mengikuti ekstrakukrikuler olahraga di SMP Negeri 1 Prambanan tahun ajaran 2012/2013. 2014. [cited 2015 Oct 15]. Available from: http://eprints.uny.ac.id/16436/1/SKRIP SI\%20RAVERI\%20FEBRI\%20NUGR AHA-NIM\%2008603141038.pdf

6. Kapoor S, Kapoor AK. Body Structure and Respiration Efficiency among High Altitude Himalayan Population. 2003. [cited 2016 Feb 17]. Available from: http://hrcak.srce.hr/file/7980

7. LIPK Tomohon. Profil Tomohon. 2012. [cited 2016 Mar 31]. Available from: https://lipktomohon.wordpress.com/pro fil-tomohon/

8. Pemerintah Kota Manado. Letak Geografis. 2012. [cited 2016 Mar 31]. Available from

http://www.manadokota.go.id/page101-geografis.html. 